\title{
114. Effects of Ca Ion and ADP on Superprecipitation of Myosin B from Slime Mold, Physarum polycephalum
}

\author{
By Kazuhiro Kohama, Keiko Kobayashi, and Shohei Mitani \\ Department of Pharmacology, Faculty of Medicine, \\ The University of Tokyo, Tokyo 113
}

(Communicated by Setsuro EbASHI, M. J. A., Nov. 12, 1980)

Introduction. It is well established that $\mathrm{Ca}$ ion regulates contractile processes of muscle. ${ }^{1)}$ It is also evident that $\mathrm{Ca}$ ion is involved in non-muscle cell motility. But it is not certain whether $\mathrm{Ca}$ ion stimulates $^{2), 3)}$ or inhibits ${ }^{4)}$ the cell motility. Recently Ca-sensitizing factors which inhibit actin polymerization, ${ }^{5), 6)}$ gelation $^{7)-9)}$ and/or actin-myosin interaction ${ }^{9)}$ in the presence of $\mathrm{Ca}$ ion have been prepared from non-muscle cells.

Ca-sensitive myosin B has been prepared from slime mold, Physarum polycephalum. ${ }^{10), 11)}$ The superprecipitation and the ATPase activity of the preparation were stimulated in the presence of $\mathrm{Ca}$ ion. A strong ATPase other than myosin ATPase, however, was then isolated from Physarum polycephalum. ${ }^{12), 13)}$ Its activity was stimulated in the presence of $\mathrm{Ca}$ ion. This suggests that the Ca-sensitive myosin B might be contaminated by such a Ca-dependent ATPase.

This article reports that myosin B of which the superprecipitation is inhibited in the presence of $\mathrm{Ca}$ ion has been prepared from Physarum polycephalum and suggests that the inhibition is induced by a Ca-sensitizing factor(s) present in the myosin B preparation. It is also shown that adenylate kinase activity is found in such a myosin B preparation.

Materials. Micro-plasmodium of Physarum polycephalum was grown in semi-defined medium described by Daniel and Rusch. ${ }^{14)}$ Hexokinase from yeast (E.C. 2.7.1.1) was purchased from Sigma.

Methods. All procedures for protein preparation were carried out at about $4^{\circ} \mathrm{C}$.

Preparation of crude myosin B. Method I-The micro-plasmodium was homogenized by Polytron in 2 volumes of Guba-Straub solution containing $15 \mathrm{mM}$ glycoletherdiamine tetraacetic acid (GEDTA), $15 \mathrm{mM} 2$-mercaptoethanol (ME) and $75 \mathrm{KIU} / \mathrm{ml}$ of Trasylol. The homogenate was mixed with $1 \mathrm{~N} \mathrm{NaOH}$ to give $\mathrm{pH} 8.4$, left standing at $0^{\circ} \mathrm{C}$ for $1 \mathrm{hr}$, and centrifuged at $100,000 \times g$ for $45 \mathrm{~min} .{ }^{15}$ ) The supernatant was mixed with $1 \mathrm{~N} \mathrm{HCl}$ to give $\mathrm{pH}$ 6.5. It was then 
mixed with 9 volumes of $10 \mathrm{mM} \mathrm{ME}$ and $45 \mathrm{mM} \mathrm{MgCl}$ and left standing for about $10 \mathrm{hr}$. The resulting precipitate was collected by the centrifugation at $10,000 \times g$ for $30 \mathrm{~min}$ and dissolved in $0.5 \mathrm{M} \mathrm{KCl}$ containing $10 \mathrm{mM}$ phosphate buffer $(\mathrm{pH} \mathrm{7.6)}$ and $10 \mathrm{mM} \mathrm{ME}$.

Method II-The steps up to preparing $100,000 \times g$ supernatant of which the $\mathrm{pH}$ had been adjusted to $\mathrm{pH} 6.5$ were the same as Method I. The supernatant was then dialyzed against 9 volumes of $10 \mathrm{mM} \mathrm{ME}$ and was centrifuged at $10,000 \times g$ for $10 \mathrm{~min}$. The resulting precipitate was dissolved in $0.5 \mathrm{M} \mathrm{KCl}$ containing $10 \mathrm{mM}$ phosphate buffer ( $\mathrm{pH} 6.8$ ) and $10 \mathrm{mM} \mathrm{ME}$.

Purification of myosin $B$. Crude myosin B was dialyzed against 9 volumes of $10 \mathrm{mM} \mathrm{ME}$ and was centrifuged at $10,000 \times g$ for $10 \mathrm{~min}$. After washing with $50 \mathrm{mM} \mathrm{KCl}$ containing $10 \mathrm{mM} \mathrm{ME}$ and $1 \mathrm{mM}$ $\mathrm{NaHCO}_{3}$, the precipitate was dissolved in $0.5 \mathrm{M} \mathrm{KCl}$ containing $10 \mathrm{mM}$ $\mathrm{ME}$ and $1 \mathrm{mM} \mathrm{NaHCO}_{3}$. This precipitation-dissolution cycle was repeated two or three times.

Preparation of myosin. Myosin B was dissolved in a solution containing $10 \mathrm{mM} \mathrm{ME}, 5 \mathrm{mM}$ phosphate buffer $(\mathrm{pH} 7.6)$ and $40 \mathrm{mM}$ sodium pyrophosphate adjusted to $\mathrm{pH} 7.6$ by $\mathrm{HCl}$ and then applied to DEAE-cellulose column equilibrated with the same solution. After removing non-absorbing material from the column, myosin was eluted with $0.13 \mathrm{M} \mathrm{NaCl}$ containing $10 \mathrm{mM} \mathrm{ME}, 5 \mathrm{mM}$ phosphate buffer ( $\mathrm{pH} 7.6$ ) and $40 \mathrm{mM}$ sodium pyrophosphate $(\mathrm{pH} 7.6)$.

The SDS polyacrylamide gel electrophoresis of myosin preparation thus obtained showed three bands corresponding to heavy chain, about $230 \mathrm{~K}$ in its molecular weight, and two light chains, about $17 \mathrm{~K}$ and $14 \mathrm{~K}$, respectively (cf. ref. 16,17 ). In addition to these, a protein of about $250 \mathrm{~K}$ was found in it.

The concentration of nuclectides was determined by high performance liquid chromatography of $\mu$-bondapack $\mathrm{C}_{18}$ column (Waters Associates). ATP (Sigma) and ADP (Yamasa-Shoyu) were contaminated with trace ADP and about $1 \%$ of ATP, respectively.

Preparation of actin. Micro-plasmodium was treated with acetone to make acetone powder. Crude actin was extracted from the acetone powder by $1 \mathrm{mM}$ ATP containing $5 \mathrm{mM} \mathrm{ME}$ at $\mathrm{pH}$ 7.6. Actin was purified by repeating polymedization and depolymerization at $0.1 \mathrm{M} \mathrm{NaCl}$ containing $1 \mathrm{mM}$ GEDTA, $1 \mathrm{mM}$ ATP, $5 \mathrm{mM} \mathrm{ME}$ and $20 \mathrm{mM}$ Tris-maleate buffer $(\mathrm{pH}$ 7.5) and at $1 \mathrm{mM}$ ATP containing $0.1 \mathrm{mM} \mathrm{CaCl}_{2}, 5 \mathrm{mM} \mathrm{ME}$ and $2 \mathrm{mM} \mathrm{NaHCO}_{3}$, respectively.

Preparation of tropomyosin. Tropomyosin was prepared from rabbit skeletal muscle by the method of Ebashi et al. ${ }^{18)}$

Superprecipitation. Superprecipitation experiments were carried

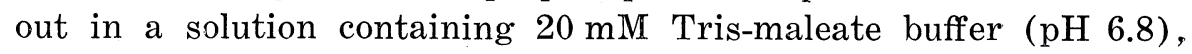


$8 \mathrm{mM} \mathrm{MgCl}_{2}, \mathrm{Ca}$ - or Sr-GEDTA buffer and appropriate concentrations of ATP and $\mathrm{KCl}$. Reaction was measured by the method described by Ebashi. ${ }^{19)}$

Other methods. Protein concentration was determined by biuret reaction. Purity of proteins was checked by SDS polyacrylamide gel electrophoresis. ${ }^{20)}$

Results and discussion. Effect of divalent cations. Crude myo$\sin \mathrm{B}$ superprecipitated more rapidly in the presence of $10^{-5} \mathrm{M}$ Ca ion than in the absence of Ca ion (not illustrated). This is in agreement with earlier reports. ${ }^{10), 11)}$

However, purified myosin B superpecipitated in the presence of Ca ion above $10^{-6} \mathrm{M}$ more slowly than in the absence of Ca ion (Fig. 1). Disappearance of $\mathrm{Ca}$ ion activation may be explained by the removal from crude myosin B of Ca-dependent non-myosin ATPase, ${ }^{12)}{ }^{13)}$ which was referred to in Introduction. It is now very likely that the activation of myosin $\mathrm{B}$ by $\mathrm{Ca}$ ion is not the intrinsic property of the contractile system of Physarum polycephalum.

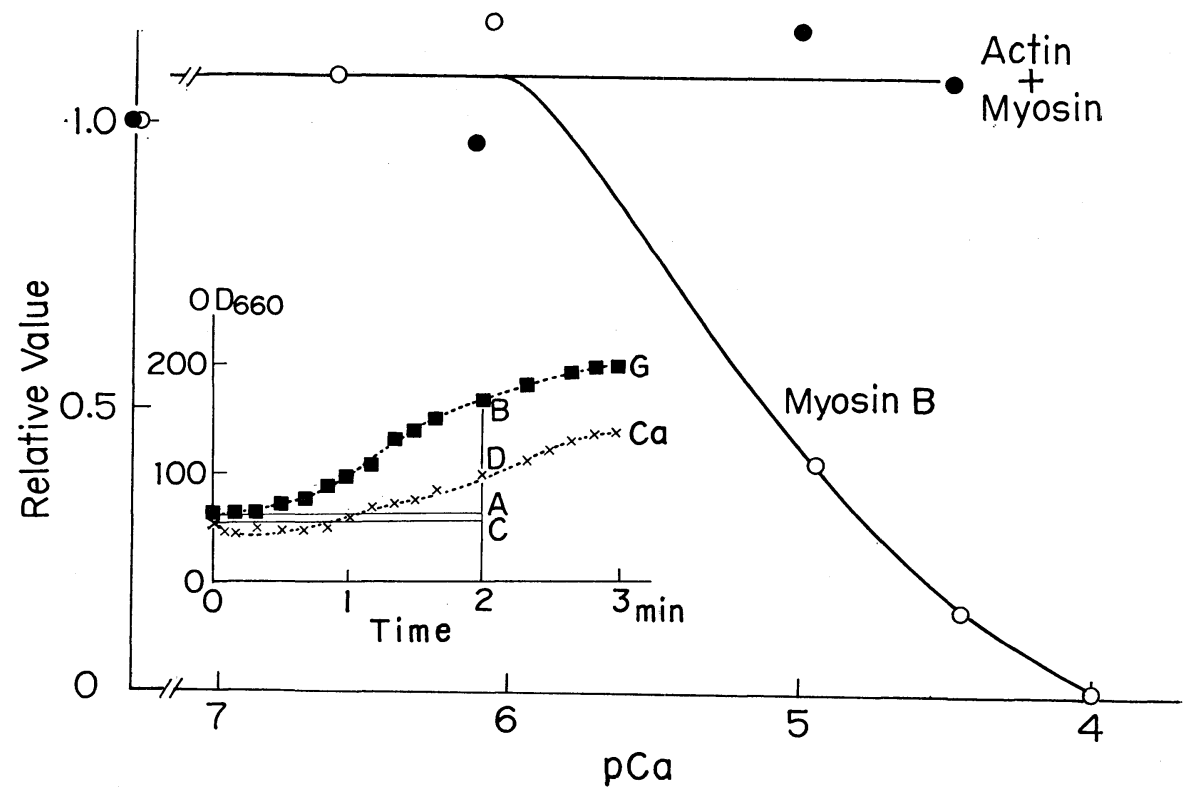

Fig. 1. Effect of $\mathrm{Ca}$ ion on superprecipitation of myosin $\mathrm{B}$ and synthetic actomyosin. The extents of superprecipitation at various concentration of $\mathrm{Ca}$ ion relative to those in the presence of GEDTA were plotted against pCa. - $\mathrm{O}-$ myosin B; - - , synthetic actomyosin (designated as Actin+ Myosin in the figure). The procedure to determine the relative extent is illustrated in the inset: Superprecipitation of myosin B was induced in the presence of GEDTA (-----, G) or of $10^{-5} \mathrm{M} \mathrm{Ca}$ ion $(--\times--, \mathrm{Ca})$, and the ratio of $\mathrm{CD}$ to $\mathrm{AB}$ was plotted as an open symbol at pCa 5 . 
The rate of superprecipitation of synthetic actomyosin, much purer than purified myosin $\mathrm{B}$, was not influenced by $\mathrm{Ca}$ ion below $3 \times 10^{-5} \mathrm{M}$ (Fig. 1). This fact clearly indicates that a Ca-sensitizing fator(s) other than actin and myosin should be involved in the Casensitivity of superprecipitation of myosin B.

Ca-sensitivity of superprecipitation of myosin B was not affected by tropomyosin. As tropomyosin inhibited the Ca-dependent effect of fragmin on actin polymerization, ${ }^{21)}$ fragmin might not be involved in the Ca-sensitivity of superprecipitation.

$\mathrm{Sr}$ ion above $5 \times 10^{-5} \mathrm{M}$, in place of $\mathrm{Ca}$ ion, also showed an inhibitory effect on superprecipitation (not illustrated).

In the presence of constant amount of $\mathrm{Mg}$-ATP, superprecipitation of myosin B was enhanced by high concentrations of free $\mathrm{Mg}$ ion, i.e. above $5 \times 10^{-3} \mathrm{M}$. Since this is true of synthetic actomyosin, $\mathrm{Mg}$ ion should affect actin and/or myosin, not Ca-sensitizing factor(s).

Effects of ADP. Superprecipitation of myosin B was enhanced when ATP was mixed with a small amount of ADP, $1 \%$ of ATP (not illustrated).

ADP above $4 \times 10^{-5} \mathrm{M}$ induced superprecipitation (Fig. 2). Since $4 \times 10^{-6}$ M ATP was required to induce superprecipitation (not illustrated), and the amount of ATP contained in ADP preparations was only $1 \%$ of $\mathrm{ADP}$, the contaminating ATP was not responsible for inducing superprecipitation. With hexokinase and glucose were mixed

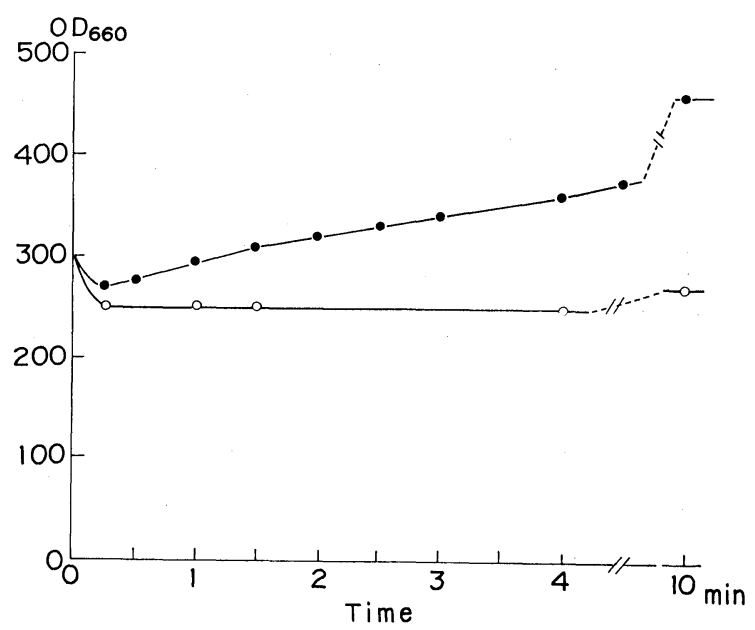

Fig. 2. Effect of ADP on superprecipitation of myosin B. Superprecipitation of myosin $\mathrm{B}$ was induced by $4 \times 10^{-5} \mathrm{M}$ ADP alone (- -) or $4 \times 10^{-5} \mathrm{M}$ ADP in the presence of hexokinase and glucose (-O-). The latter agents were expected to eliminate ATP produced from ADP by adenylate kinase activity in myosin B. 


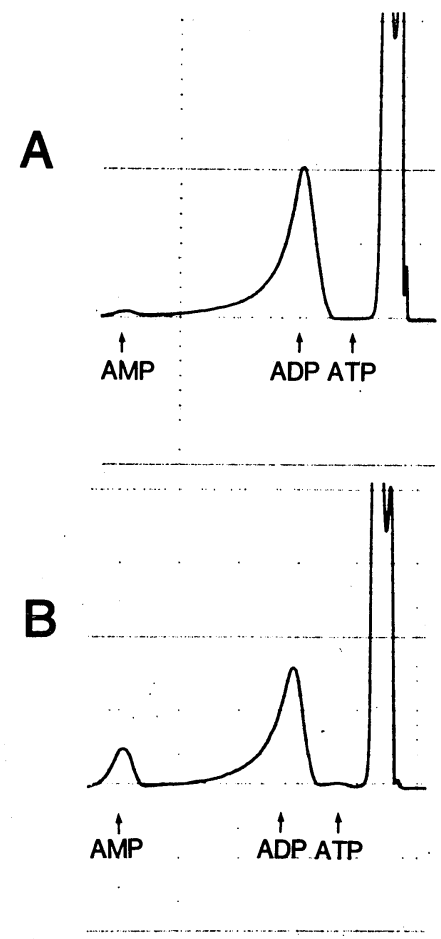

Fig. 3. High performance liquid chromatogram of the product of ADP incubated with myosin B. $5 \times 10^{-4} \mathrm{M}$ ADP was mixed with myosin $B$ suspended in a solution containing $10 \mathrm{mIM} \mathrm{KCl}, 10^{-5} \mathrm{M}$ $\mathrm{Ca}$ ion, $8 \mathrm{mM} \mathrm{MgCl}_{2}$ and $20 \mathrm{mM}$ Tris-maleate buffer ( $\mathrm{pH} 6.8$ ). Equal amount of methanol was mixed with the solution before (A) or after (B) $30 \mathrm{~min}$ incubation at $25^{\circ} \mathrm{C}$. The traces show absorbance at $254 \mathrm{~nm}$ of ATP, ADP or AMP.

with incubation mixture, not the superprecipitation by ATP but only clearing phenomenon was observed (Fig. 2). After incubating ADP with myosin B, a part of ADP was converted to AMP (Fig. 3). These facts indicate that myosin $B$ preparation contains adenylate kinase activity and that ADP itself has a dissociating action on actomyosin (cf. ref. 3).

Since no phosphagen like creatine phosphate or arginine phosphate has been found in Physarum polycephalum, adenylate kinase activity may play a physiological role in regenerating ATP from ADP.

Superprecipitation induced by ADP were less sensitive to $\mathrm{Ca}$ ion than that induced by ATP (not illustrated).

Conclusion. Ca ion inhibits the superprecipitation of myosin B of Physarum polycephalum, but does not affect that of pure actomyosin. The presence in myosin B of a Ca-sensitizing factor(s) which is distinct from fragmin is suggested. 
Acknowledgements. This work was supported in part by the grants from the Ministry of Education, Science and Culture of Japan, Introchemical Foundation, and the Muscular Dystrophy Association of America, Inc.

The authors wish to express their gratitude to Prof. S. Ebashi for discussions and encouragement and to Prof. J. Ohta for advice about cultivating micro-plasmodium of Physarum polycephalum. K. Kobayashi is a graduate student of Ochanomizu University and S. Mitani a medical student of the University of Tokyo.

\section{References}

1) Ebashi, S. (1980): Proc. R. Soc. Lond., B207, 259-286.

2) Ridgway, E. B., and Durham, A. C. H. (1976) : J. Cell Biol., 69, 223-226.

3) Ueda, T., Götz von Olenhusen, K., and Wohlfarth-Bottermann, K. E. (1978): Cytobiol., 18, 76-94.

4) Williamson, R. E. (1975) : J. Cell Sci., 17, 655-668 (1975).

5) Hasegawa, T., Takahashi, S., Hayashi, H., and Hatano, S. (1980) : Biochem., 19, 2677-2683.

6) Kendrick-Jones, J., Jakes, R., Nyström, L.-E., and Lindberg, U. (1979) : Peptides of the Biological Fluids. Pergamon Press, pp. 493-498.

7) Yin, H. L., and Stossel, T. P. (1979) : Nature, 281, 583-586.

8) Miura, N., and Asano, A. (1979): Nature, 282, 44-48.

9) Stendahl, O. I., and Stossel, T. P. (1980): Biochem. Biophys. Res. Commun., 92, 675-681.

10) Nachmias, V., and Asch, A. (1974): Biochem. Biophys. Res. Commun., 60, $656-664$.

11) Kato, T., and Tonomura, Y. (1975): J. Biochem., 77, 1127-1134.

12) Matsumura, F., and Hatano, S. (1973): Abstr. 12th Med. Biophys. Soc. Japan, Tokyo, p. 36 (in Japanese).

13) Kawamura, M., and Nagano, K. (1975): Biochim. Biophys. Acta, 397, 207-209.

14) Daniel, J. W., and Rusch, H. P. (1961) : J. Gen. Microbiol., 25, 47-59.

15) Hatano, S., and Tazawa, M. (1968) : Biochim. Biophys. Acta., 154, 507-519.

16) Nachmias, V. T. (1974): J. Cell Biol., 62, 54-65.

17) Greene, L. E., and Yount, R. G. (1977) : Biochim. Biophys. Acta, 480, 326332.

18) Ebashi, S., Kodama, A., and Ebashi, F. (1968): J. Biochem., 64, 465-477.

19) Ebashi, S. (1961) : J. Biochem., 50, 236-244.

20) Laemmli, U. K. (1970): Nature, 227, 680-685.

21) Sugino, H., Hasegawa, T., and Hatano, S. (1979): Abstr. 17th Meet. Biophys. Soc. Japan, Nagoya, p. 130 (in Japanese). 